
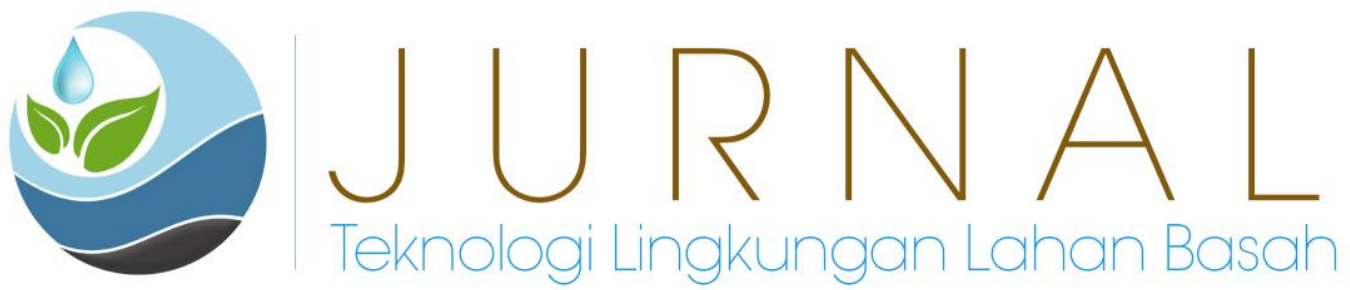

\title{
EFISIENSI PENGOLAHAN LIMBAH CAIR HOTEL MENGGUNAKAN MOVING BED BIOFILM REACTOR (MBBR)
}

\author{
Dhuhan $^{1}$, Laili Fitria ${ }^{1}$, dan Ulli Kadaria ${ }^{1}$ \\ ${ }^{1}$ Jurusan Teknik Lingkungan Universitas Tanjungpura \\ E-mail : aandhuhan@gmail.com
}

\begin{abstract}
The increase in the number of hotels in Pontianak City has a impact, namely the increase in the generation of wastewater. The hotel wastewater treatment process is widely used by hotels in Pontianak, especially at the Aston hotel, which already has a sewage treatment plant with suspended biological treatment. The processed water often does not meet the quality standards of wastewater which may be disposed of in accordance with PERMEN/LH/68/2016 concerning domestic wastewater quality standards. In this study, the parameters measured were BOD, TSS and pH. The purpose of this study was to determine the efficiency of Aston hotel wastewater treatment using an attached reactorMBBR (moving bed biofilm reactor) with Kaldnes K3 media in reducing BOD and TSS parameters. Growing microorganisms and biofilms on adhesive media for 14 days. Giving Kaldnes K3 adhesive media as much as 30\%. Based on the research results of Aston hotel wastewater treatment with attached reactor MBBR able to reduce BOD and TSS parameters. Best lowering efficiency in attached reactor MBBR with the best time of 7 days was able to reduce the BOD parameter from $109.81 \mathrm{mg} / \mathrm{L}$ became $7.28 \mathrm{mg} / \mathrm{L}$ with an efficiency of $93.37 \%$, and the TSS parameter decreased from the initial concentration of $78 \mathrm{mg} / \mathrm{L}$ to $8 \mathrm{mg} / \mathrm{L}$ and the efficiency was $89.74 \%$.
\end{abstract}

Keywords : BOD, Kaldnes, Hotel Waste Waste, MBBR, TSS

\begin{abstract}
Abstrak
Peningkatan jumlah hotel di Kota Pontianak memberi dampak, yaitu meningkatnya timbulan limbah cair. Proses pengolahan air limbah hotel banyak digunakan hotel-hotel di Pontianak. Hotel Aston telah memiliki instalasi pengolahan limbah dengan pengolahan biologi tersuspensi. Air hasil olahannya sering kali belum memenuhi baku mutu air limbah yang boleh dibuang sesuai dengan PERMEN/ LH/ 68/ 2016 tentang baku mutu air limbah domestik. Pada penelitian ini parameter yang diukur yaitu BOD, TSS dan pH. Tujuan dari penelitian ini adalah untuk mengetahui efisiensi pengolahan limbah cair hotel Aston menggunakan reaktor terlekat MBBR (moving bed biofilm reactor) dengan media Kaldnes K3 dalam menurunkan parameter BOD dan TSS. Dilakukan penumbuhan mikroorganisme dan biofilm pada media lekat K3 selama 14 hari. Pemberian media lekat Kaldnes K3 sebanyak 30\% dari volume reaktor. Berdasarkan hasil penelitian, pengolahan limbah cair hotel Aston dengan reaktor terlekat $M B B R$ mampu menurunkan parameter BOD dan TSS. Efisiensi penurunan terbaik pada reaktor terlekat $M B B R$ dengan waktu 7 hari, mampu menurunkan parameter BOD dari 109,81 mg/L menjadi 7,28 mg/L dengan efisiensi 93,37 \%, dan penurunan parameter TSS dari konsentrasi awal $78 \mathrm{mg} / \mathrm{L}$ menjadi $8 \mathrm{mg} / \mathrm{L}$ (efisiensi 89,74\%).
\end{abstract}

Kata Kunci : BOD, Kaldnes, Limbah Cair Hotel, MBBR, TSS. 


\section{PENDAHULUAN}

Peningkatan jumlah hotel di Kota Pontianak memberi dampak negatif, yaitu meningkatnya timbulan limbah cair. Apabila permasalahan limbah cair ini tidak ditanggulangi dengan cara yang tepat, dapat menimbulkan pencemaran lingkungan di badan air penerima yang akan berdampak pula pada manusia dan makhluk hidup lainnya.

Hotel Aston sudah memiliki instalasi pengolahan limbah dengan pengolahan biologi tersuspensi proses lumpur aktif (activated sludge). Berdasarkan pengujian oleh petugas sampling di BLHK pada tanggal 24 November 2018 bahwa parameter BOD dan TSS berturut-turut adalah $253 \mathrm{mg} / \mathrm{l}$ dan $120 \mathrm{mg} / \mathrm{l}$. Nilai tersebut masih melebihi standar baku mutu Peraturan Menteri Lingkungan Hidup dan Kehutanan Nomor P.68/MenLH/Setjen/Kum/1/8/2016 tentang Baku Mutu Air Limbah Domestik dimana untuk parameter BOD dan TSS adalah $30 \mathrm{mg} / \mathrm{l}$ dan $30 \mathrm{mg} / \mathrm{l}$. Maka dari itu perlu adanya proses pengolahan biologi terlekat dengan metode yang efisien dalam pengolahan limbah hotel. Metode yang telah dikaji dan dapat digunakan adalah dengan menggunakan kombinasi metode Moving Bed Biofilm Reactor (MBBR).

Metode Moving Bed Biofilm Reactor (MBBR) memerlukan media lekat seperti Kaldnes. Kaldnes memiliki beberapa tipe yang terkenal di Indonesia seperti Kaldnes K1, Kaldnes K3, dan Kaldnes K5 Menurut Kholif (2018) penurunan beban pencemar pada limbah domestik dengan menggunakan Moving Bed Biofilm Reactor (MBBR) dengan media Kaldnes K1 (media isian 30\%), waktu terbaik pada hari ke-7 memiliki efisiensi pengolahan kadar BOD sebesar 83,3\%. Sedangkan efisiensi COD sebesar 84.2\%, Kadar efisiensi TSS sebesar 90\%. Menurut Kusuma (2019), pengolahan limbah laundry dengan metode Moving Bed Biofilm Reactor (MBBR) dengan media Kaldnes K1 (media isian $20 \%$ ) mampu menurunkan parameter COD, BOD, Phosfat, dan Surfaktan. Untuk efisiensi penurunan terbaik terletak pada hari ke 10 pengolahan sebesar $91 \%$ untuk BOD, efisiensi COD sebesar 93,81\%, efisiensi Phosfat sebesar 86,10\%, dan efisiensi Surfaktan sebesar 88,22

\section{METODE PENELITIAN}

\section{A. Lokasi dan Waktu Penelitian}

Penelitian dilakukan pada Januari 2021, lokasi penelitian dilakukan di Workshop Teknik Lingkungan Fakultas Teknik Universitas Tanjungpura sebagai lokasi percobaan alat dan Laboratorium PT Superintending Company Of Indonesia (SUCOFINDO) Pontianak sebagai lokasi uji sampel air limbah sebelum dan sesudah diolah. Lokasi Pengambilan sampel yaitu Aston Pontianak Hotel \& Convention Center di Kota Pontianak.

\section{B. Pengambilan Limbah Cair}

Pengambilan limbah cair dilakukan di Hotel Aston yang berlokasi di Jalan Gajah Mada Kota Pontianak. Sampel air limbah diambil pada bak equalizing atau bak pencampuran di IPAL Hotel Aston dengan volume 110 liter. Pengambilan sampel ini mengacu pada SNI.6989.57-2008 tentang grab sampling air limbah yang diambil sesaat pada lokasi tertentu.

\section{Alat dan Bahan}

Alat yang digunakan dalam penelitian ini antara lain, 4 buah reaktor terbuat dari kaca dengan dimensi panjang $28 \mathrm{~cm}$ x lebar $28 \mathrm{~cm}$ x tinggi $28 \mathrm{~cm}$, kayu untuk pembuatan dudukan bak reaktor, kemudian 7 buah aerator (Amara BS 410) dengan daya 5 watt, selanjutnya jirigen 25 liter sebanyak 6 buah untuk pengambilan limbah cair dari Hotel Aston, botol 1500ml sebanyak 5 buah untuk pengambilan sampel limbah cair Hotel Aston 
sebelum dan sesudah diolah. Bahan yang digunakan dalam penelitian ini antara lain limbah cair Hotel Aston sebanyak 120 liter yang akan dibagikan ke setiap reaktor sebanyak 15 liter dan media kaldness K3 sebanyak 13,5 liter.

\section{Prosedur Kerja}

\section{Rancangan Alat}

Alat terdiri dari bak kaca dengan ukuran volume 22 liter dan aerator. Pembuatan alat dilakukan di Workshop Teknik Lingkungan Universitas Tanjungpura Pontianak. Dimensi reaktor yaitu panjang $28 \mathrm{~cm}$ x lebar $28 \mathrm{~cm}$ x tinggi $28 \mathrm{~cm}$ yang terdiri dari 3 bak pengolahan dan 1 bak kontrol.

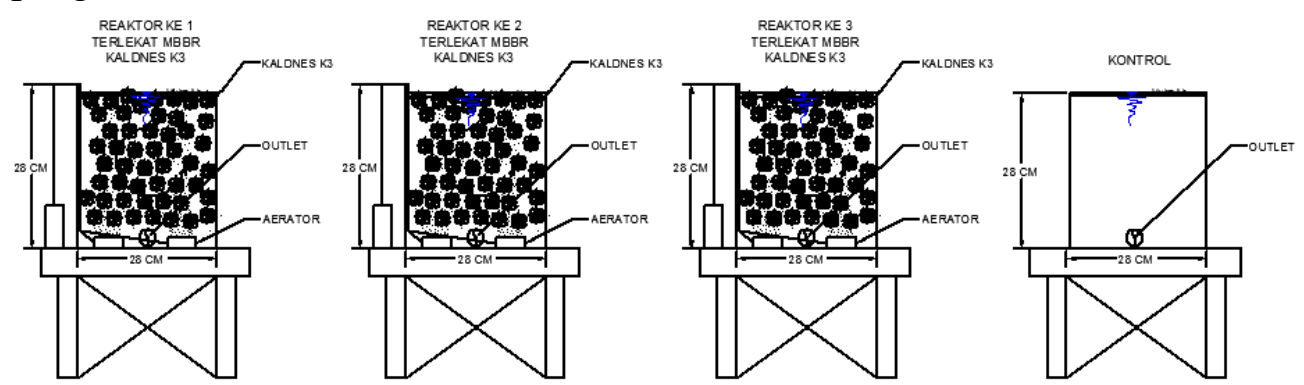

Gambar 1. Rancangan Reaktor Penelitian

\section{Menghitung Volume Reaktor dan Volume Media Kaldnes K3}

Bak reaktor dengan ukuran $28 \mathrm{~cm}$ x $28 \mathrm{~cm}$ x $28 \mathrm{~cm}$ didapatkan ukuran volume sebesar 22 liter. Volume limbah Hotel Aston yang digunakan yaitu 15 liter/ bak. Untuk volume media Kaldnes K3 menurut Kholif (2018) 30\% dari total limbah yang akan diolah. Total volume media Kaldnes adalah 4,5 liter.

\section{Seeding Aklimatisasi}

Proses pengembangbiakan mikroorganisme (seeding) untuk menumbuhkan mikroorganisme secara alami. Pertama dilakukan sampling air limbah Hotel Aston sebanyak 120 liter air limbah dari bak equalizing di ipal Hotel Aston, 120 liter air limbah dibagi kesetiap reaktor sebanyak 15 liter. Selanjutnya dilakukan seeding media lekat Kaldnes K3. Reaktor diberi aerasi selama \pm 14 hari dalam bak reaktor ukuran panjang $28 \mathrm{~cm}$ x lebar $28 \mathrm{~cm}$ x tinggi $28 \mathrm{~cm}$. Selama proses berlangsung, $\mathrm{pH}$ dan suhu dihitung setiap hari dengan kisaran nilai untuk $\mathrm{pH}$ sebesar 6,5 - 7,5 dan suhu $25-35^{\circ}$ C (Sihite, 2015). Setelah terlihat adanya biofilm pada media lekat media seeding telah siap yang juga ditandai dengan $\mathrm{pH}$ netral sebesar $6,5-7,5$ dan suhu sekitar $25^{\circ}-35^{\circ} \mathrm{C}$. Media seeding yang telah siap kemudian air limbah bekas seeding di buang lalu diganti dengan air limbah baru untuk mengolah limbah cair Hotel Aston. Penelitian ini dilakukan aklimatisasi langsung pada proses seeding langsung menggunakan limbah Hotel dan diberi sedimen lumpur yang berasal dari pengolahan limbah hotel tersebut, dengan kata lain hanya mengharapkan pertumbuhan dari mikroorganisme asal (indigenous) pada limbah cair dan lumpur dari pengolahan Hotel Aston sehingga seeding dan aklimatisasi dilakukan bersamaan di dalam reaktor.

\section{Running}

Bak reaktor dengan volume 22 liter dengan dimensi panjang $28 \mathrm{~cm}$ x lebar $28 \mathrm{~cm} \mathrm{x}$ tinggi $28 \mathrm{~cm}$ yang terbuat dari kaca, terdiri dari 4 bak reaktor yaitu 3 reaktor pengulangan pengolahan terlekat dengan metode Moving Bed Biofilm Reactor (MBBR) dengan media lekat Kaldness K3, dan 1 reaktor bak kontrol. Limbah dari Hotel Aston di campurkan menjadi satu sebanyak 120 liter kemudian limbah hotel dibagikan pada masing-masing bak reaktor sebanyak 15 liter. Ditambahkan media Kaldnes K3 yang sudah seeding sebanyak 30\% media dari total volume limbah di dalam reaktor yaitu 4,5 liter. Terdapat aerator utuk memberikan oksigen yang cukup dan membuat gerakan pada media kaldnes K3 agar tidak menggumpal. Selanjutnya 
diambil waktu terbaik yaitu hari ke-7 untuk mengetahui efisiensi dalam pengolahan limbah cair hotel, waktu terbaik pada hari ke-7 (Kholif, 2018). Setelah mencapai hari ke-7 air limbah yang sudah di olah diambil dari saluran outlet sebanyak 1,5liter cara pengambilan limbah yang sudah di olah sesuai dengan SNI 6989.57.2008 tentang air dan air limbah.

\section{E. Analisis Data}

Analisa data yang akan dilakukan yaitu dengan menyajikan data dalam bentuk tabel maupun grafik. Sebelum dilakukan perhitungan persentase efisiensi penurunan parameter pencemar pada pengolahan terlebih dahulu dilakukan rata-rata dari tiga kali ulangan (triplo), dapat dilihat dari persamaan :

Rata-rata $x=\frac{1}{n}\left(x_{1}+x_{2}+\cdots+x_{n}\right)$

Keterangan:

$x=$ rata-rata hitung

$x_{1}=$ nilai sampel ke- $i$

$n=$ jumlah sampel

Ef $=\frac{\text { Nilai Awal-Nilai Akhir }}{\text { Nilai Awal }} \times 100 \%$

\section{HASIL DAN PEMBAHASAN}

\section{A. Karakteristik Air Limbah}

Air limbah yang digunakan berasal dari limbah cair Hotel Aston Pontianak di Jl. Gajahmada. Sampel awal limbah yang diambil sebanyak $1500 \mathrm{ml}$. Sampel awal diuji di Laboratorium PT Superintending Company of Indonesia (SUCOFINDO). Hasil pengujian sampel awal limbah cair Hotel Aston dapat dilihat pada tabel 1.

Tabel 1. Karakteristik Limbah Hotel Aston

\begin{tabular}{ccccccc}
\hline NO & $\begin{array}{c}\text { PARA- } \\
\text { METER }\end{array}$ & PERLAKUAN & SATUAN & $\begin{array}{c}\text { KONSENTRASI } \\
\text { AWAL }\end{array}$ & $\begin{array}{c}\text { SETELAH } \\
\text { DIOLAH }\end{array}$ & $\begin{array}{c}\text { *BAKU } \\
\text { MUTU } \\
(\mathrm{mg} / \mathrm{l})\end{array}$ \\
\hline \multirow{2}{*}{1} & $\mathrm{pH}$ & $\begin{array}{c}\text { Terlekat } \\
\text { Kontrol }\end{array}$ & Nilai $\mathrm{pH}$ & 6,3 & 6,9 & $6-9$ \\
2 & BOD & $\begin{array}{c}\text { Terlekat } \\
\text { Kontrol }\end{array}$ & mg/L & 109,81 & 7,9 & 7,28 \\
& & Terlekat & mg/L & 78 & 83,2 & 30 \\
3 & TSS & Kontrol & & 50 & 30 \\
\hline
\end{tabular}

*Baku Mutu Berdasarkan PermenLHK/68/2016

Pengujian sampel awal dilakukan untuk mengetahui nilai $\mathrm{pH}, \mathrm{BOD}$, dan TSS dari air limbah Hotel Aston. Nilai masing-masing parameter pada sampel awal limbah cair Hotel Aston yaitu nilai BOD sebesar 109,81 mg/l, nilai TSS sebesar 78,00 mg/l dan nilai $\mathrm{pH}$ sebesar 6,3. Berdasarkan hasil pengujian nilai parameter limbah cair melebihi batas baku mutu PerMen LH nomor 68 tahun 2016 tentang baku mutu air limbah domestik dan memerlukan pengolahan sebelum dialirkan ke drainase. Nilai baku mutu yang diizinkan untuk parameter BOD dan TSS tidak boleh lebih dari $30 \mathrm{mg} / \mathrm{L}$ sedangkan $\mathrm{pH}$ pada rentang 6-9. Tingginya konsentrasi polutan yang terdapat pada limbah cair Hotel Aston pada penelitian ini berasal dari zat-zat organik berupa padatan yang terbawa pada keseluruhan proses pencucian baik itu pencucian peralatan masak maupun pencucian bahan atau sisa-sisa makanan pada restaurant dan proses MCK di setiap kamar yang ada di Hotel Aston. Berdasarkan hasil pengujian nilai parameter limbah cair melebihi batas baku mutu PerMen LH nomor 68 tahun 2016tentang baku mutu air limbah domestik dan memerlukan pengolahan secara khusus sebelum dialirkan ke badan air. 


\section{B. Proses Pengembangbiakan Mikroorganisme}

Pembiakan (seeding) mikroorganisme dilakukan secara alami yaitu dengan cara mengalirkan air limbah yang akan diolah ke dalam reaktor sebanyak 15 liter pada masingmasing bak, kemudian ditambahkan aerator untuk memberikan oksigen untuk mikroorganisme tersuspensi dan terlekat di dalam bak. Pada reaktor diberikan media Kaldnes K3 sebanyak 30\% dari jumlah limbah. Penggunaan media lekat Kaldnes sebanyak $30 \%$ berdasarkan penelitian (Kholif, 2018).

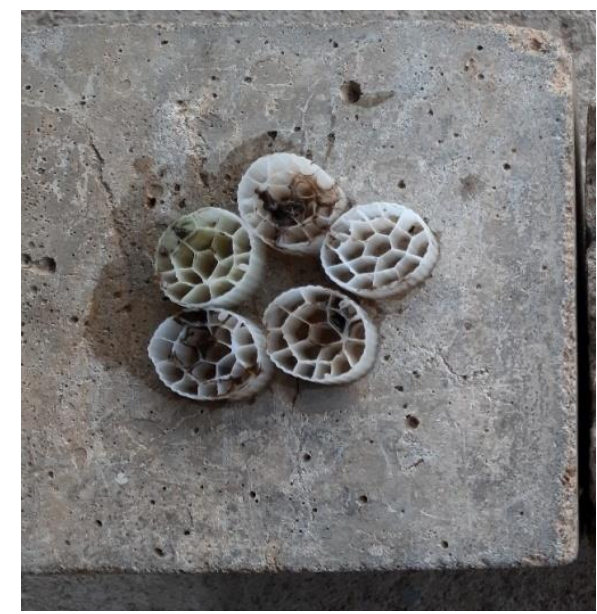

Gambar 2. Lapisan Biofilm Pada Kaldnes K3 Hari Ke-14 Seeding

Pada hari ke-14 terlihat lapisan biofilm telah tumbuh pada permukaan media Kaldnes K3 yang berwarna coklat kehitaman. Terlihat pertumbuhan mikroorganisme yang mulai optimal dengan menandakan adanya perubahan $\mathrm{pH}$ yang mulai netral yaitu pada $\mathrm{pH} 7$, hal ini mengindikasikan bakteri yang tumbuh di dalam reaktor terlekat telah mampu untuk mendegradasi senyawa pencemar yang terkandung di dalam air limbah. Mikroorganisme tumbuh, hidup berkoloni menjadi biofilm yang terdiri dari sel-sel mikroorganisme yang terbentuk dari nutrien yang cukup, terikat dan terlekat berhubungan satu dengan yang lainnya pada suatu permukaan. Mikroorganisme yang terdapat pada media lekat merupakan jenis-jenis mikroorganime seperti (fungi, algae dan protozoa) yang hidup berkoloni dan bersimbiosis untuk menguraikan zat organik (Ozkan, 2011).

Pengukuran $\mathrm{pH}$ pada proses seeding bertujuan untuk mengetahui kondisi mikroba dalam membentuk lumpur aktif dan lapisan biofilm. Selama penelitian dilakukan pengamatan terhadap $\mathrm{pH}$ dan suhu limbah cair Hotel Aston dari proses seeding hingga penelitian berlangsung. Berdasarkan hasil pengukuran $\mathrm{pH}$ yang dilakukan, $\mathrm{pH}$ air limbah yang masuk ke reaktor memiliki kondisi asam (<7). Nilai $\mathrm{pH}$ akan mempengaruhi jenis mikroorganisme yang hidup di dalam reaktor. Mikroorganisme-mikroorganisme tersebut akan melekat pada permukaan media dan juga tersuspensi di air limbah dan selanjutnya akan mengurai polutan pencemar.

Tabel 2. Data rata-rata pengukuran $\mathrm{pH}$ seeding

\begin{tabular}{cccccccccccccccc}
\hline \multirow{2}{*}{ PERLAKUAN } & $\mathbf{0}$ & $\mathbf{1}$ & $\mathbf{2}$ & $\mathbf{3}$ & $\mathbf{4}$ & $\mathbf{5}$ & $\mathbf{6}$ & $\mathbf{7}$ & $\mathbf{8}$ & $\mathbf{9}$ & $\mathbf{1 0}$ & $\mathbf{1 1}$ & $\mathbf{1 2}$ & $\mathbf{1 3}$ & $\mathbf{1 4}$ \\
\hline Terlekat & 5,3 & 5,2 & 5,4 & 5,4 & 5,6 & 5,8 & 6 & 6,4 & 6,5 & 6,6 & 6,6 & 6,8 & 6,8 & 6,9 & 7 \\
\hline
\end{tabular}


Berdasarkan data Tabel 2 maka dibuat grafik penurunan $\mathrm{pH}$ pada saat waktu seeding sebagai berikut.

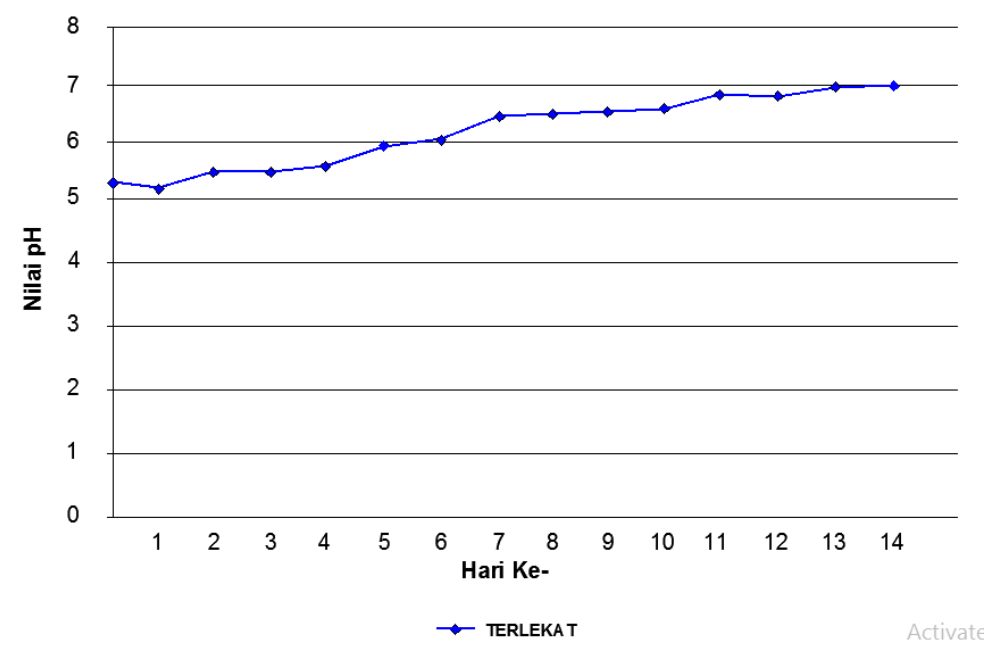

Gambar 3. Grafik rata-rata pengukuran $\mathrm{pH}$ pada proses seeding

Selama proses seeding, kisaran nilai $\mathrm{pH}$ reaktor tersuspensi dan reaktor terlekat berkisar antara 5,2 - 6,9 dan kisaran suhu antara $27^{\circ}-29^{\circ} \mathrm{C}$ Hal ini mengindikasikan mikroorganisme yang hidup di dalam reaktor adalah kelompok mikroorganisme mesofil . Mesofil memiliki klasifikasi yang beragam, termasuk dalam dua domain : bakteri dan jamur. Mesofil yang termasuk dalam domain bakteri dapat berupa gram positif atau gram negatif. Gram-positif adalah bakteri yang mempertahankan zat warna kristal violet sewaktu proses pewarnaan Gram sehingga akan berwarna biru atau ungu di bawah mikroskop. Disisi lain, bakteri gram-negatif akan berwarna merah atau merah muda.

\section{Penurunan Parameter}

Setelah melewati proses pengolahan dengan reaktor tersuspensi dan reaktor terlekat, sampel limbah cair Hotel Aston Pontianak diambil sebanyak 1500ml untuk setiap perlakuan dan pengulangan. Uji kualitas parameter BOD, dan TSS di lakukan di PT Superintending Company of Indonesia (SUCOFINDO). Hasil analisa kualitas limbah cair Hotel Aston setelah pengolahan dengan reaktor tersuspensi dan reaktor terlekat dapat dilihat sebagai berikut.

\section{Pengukuran pH Saat Running}

Nilai $\mathrm{pH}$ pada reaktor tersuspensi dan reaktor terlekat mempengaruhi proses pengolahan secara biologis, nilai pH optimum 6,5 - 8,5 (Sayekti dkk, 2012). Nilai pH yang tidak netral akan memperlambat aktivitas mikroorganisme dan dapat menyebabkan pertumbuhan jamur sehingga terjadi persaingan antara mikroorganisme dalam metabolismenya. Hasil pengukuran $\mathrm{pH}$ air limbah pada saat proses pengolahan di dalam reaktor tersuspensi dan reaktor terlekat dapat dilihat pada tabel 3. 
Tabel 3. Data rata-rata pengukuran $\mathrm{pH}$ saat pengolahan

\begin{tabular}{ccccccccc}
\hline \multirow{2}{*}{ PERLAKUAN } & $\mathbf{0}$ & $\mathbf{1}$ & $\mathbf{2}$ & $\mathbf{3}$ & $\mathbf{4}$ & $\mathbf{5}$ & $\mathbf{6}$ & $\mathbf{7}$ \\
\hline Terlekat & 6,3 & 6,6 & 6,6 & 6,5 & 6,6 & 6,7 & 6,9 & 6,9 \\
Kontrol & 6,3 & 6,6 & 7,5 & 7,5 & 7,3 & 7,2 & 6,9 & 6,8 \\
\hline
\end{tabular}

Berdasarkan data Tabel 3 maka dibuat grafik penurunan $\mathrm{pH}$ pada saat waktu Pengolahan sebagai berikut.

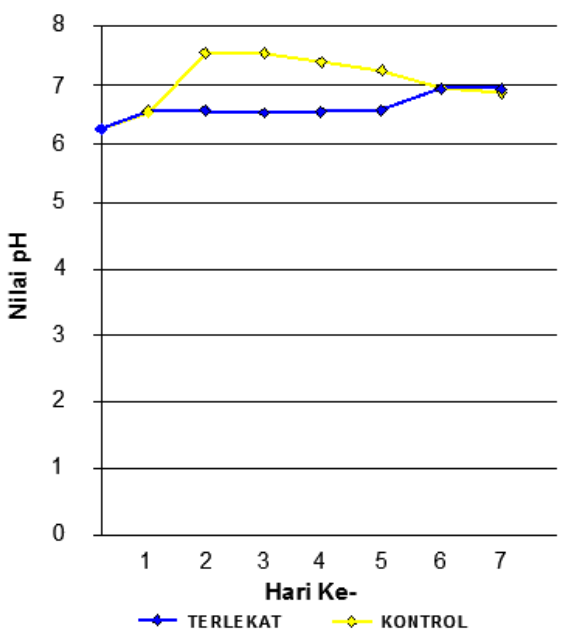

Gambar 4 Grafik rata-rata pengukuran $\mathrm{pH}$ pada proses pengolahan

Berdasarkan Gambar 4.5 menampilkan data pengukuran $\mathrm{pH}$ pada saat proses pengolahan selama 0 hari sampai 7 hari. Pada $\mathrm{pH}$ awal menunjukan nilai yang cenderung asam dengan nilai 6,3 dengan kondisi limbah baru diambil dari Hotel Aston pada jam 12.30 wib. Perlakuan terlekat menggunakan media Kaldnes K3 4,5 liter 7 hari dengan rata-rata menunjukkan nilai $\mathrm{pH}$ yang lebih tinggi yaitu 6,9. Pada bak kontrol dalam proses pengolahan selama 7 hari menunjukan nilai $\mathrm{pH}$ 6,8. Menurut Metcalf dan Eddy (2003) $\mathrm{pH}$ suatu larutan ditentukan oleh kandungan ion $\mathrm{H}^{+}$. Apabila larutan mengandung banyak ion $\mathrm{H}^{+}$(hydrogen) maka air akan mempunyai sifat $\mathrm{pH}$ asam (rendah), dan apabila dalam larutan banyak mengandung ion $\mathrm{OH}^{-}$(hidroksida) maka pH larutan menjadi basa (tinggi). Menurut Hardjowigeno (2010), pada pelepasan $\mathrm{H}+$ menyebabkan penuruan $\mathrm{pH}$.

\section{Parameter BOD}

Berdasarkan hasil penelitian yang telah dilakukan di Workshop Teknik Lingkungan, Fakultas Teknik, Universitas Tanjungpura yaitu pengukuran BOD dan efisiensi pengolahan tersuspensi dan pengolahan terlekat dengan perlakukan waktu pengambilan sampel di hari ke-0, sampai ke-7, dan bak kontrol serta tiga kali pengulangan (triplo) pada masing-masing pengukuran. Hasil rata-rata pengukuran BOD sebelum dan setelah proses pengolahan dapat dilihat pada Tabel 4.

Tabel 4 Penurunan parameter BOD

\begin{tabular}{ccccc}
\hline PERLAKUAN & $\begin{array}{c}\text { KONSENTRASI } \\
\text { AWAL (mg/l) }\end{array}$ & $\begin{array}{c}\text { SETELAH } \\
\text { DIOLAH (mg/l) }\end{array}$ & $\begin{array}{c}\text { EFEKTIVITAS } \\
\text { PENURUNAN } \\
(\boldsymbol{\%})\end{array}$ & $\begin{array}{c}* \text { BAKU MUTU } \\
(\mathbf{m g} / \mathbf{l})\end{array}$ \\
\hline TERLEKAT & 109,81 & 7,28 & 93,37 & 30 \\
KONTROL & 83,2 & 24,23 &
\end{tabular}


Limbah Hotel Aston yang diuji memiliki konsentrasi awal parameter BOD sebesar 109,81 $\mathrm{mg} / \mathrm{l}$. Limbah tersebut mengalami penurunan reaktor terlekat dengan waktu terbaik 7 hari, dengan media lekat Kaldnes K3 sebanyak 4,5 liter. Penurunan BOD pada waktu tinggal 7 hari pada reaktor terlekat memiliki penurunan yaitu 7,28 mg/L. Hasil pengamatan BOD limbah cair Hotel Aston pada bak tersuspensi dan bak terlekat dapat dilihat pada Gambar 5.

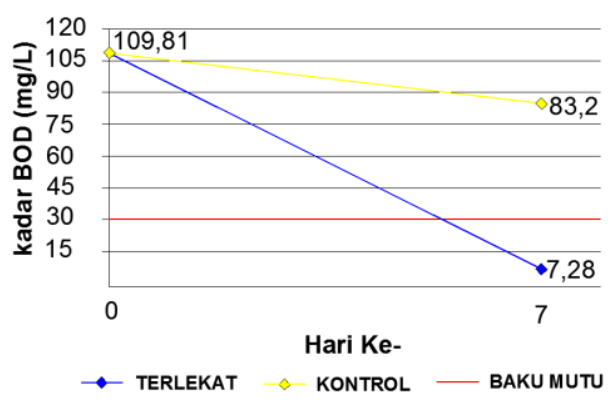

Gambar 5. Grafik rata-rata pengukuran BOD pada proses pengolahan

Penurunan pada reaktor terlekat dikarenakan mikroorganisme yang berkoloni melekat pada media Kaldnes K3 lebih cepat untuk menguraikan zat organik. Perputaran media lekat Kaldnes K3 memberikan oksigen yang cukup bagi mikroorganisme yang terdapat pada media lekat untuk proses oksidasi aerob dan mengubah bahan organik menjadi lebih sederhana dan mensintesis sel-sel baru. Pengolahan limbah cair dengan lapisan biofilm sebagian besar proses penguraian terjadi pada permukaan media lekat (MetCalf and Eddy,2003). Dalam penelitian ini, semakin lama waktu kontak media dengan limbah cair dan udara semakin besar penurunan konsentrasi BOD. Grafik penurunan parameter BOD selama pengolahan dengan reaktor tersuspensi dan reaktor terlekat dapat dilihat pada Gambar 6.

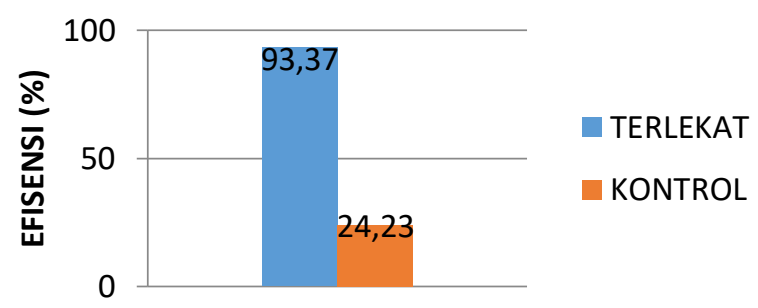

Gambar 6. Grafik efisiensi penurunan BOD

Penurunan parameter BOD pada reaktor terlekat selama 7 hari menunjukkan Efisiensi penurunan mencapai $93,37 \%$ pada reaktor terlekat selama 7 hari. Dalam penelitian Kholif (2018), waktu pengolahan selama 7 hari didapat penurunan sebesar 83,3\% untuk parameter BOD dengan pengolahan reaktor terlekat menggunakan media lekat Kaldnes sebanyak 30\%. Penurunan kadar BOD dikarenakan mikroorganisme yang terdapat pada media lekat dan mikroorganisme tersuspensi pada setiap reaktor mendegradasi zat organik yang disisihkan secara biologis.

Semakin lama waktu degradasi pada reaktor tersuspensi dan reaktor terlekat, akibatnya waktu kontak antara biomassa dengan substrat di dalam reaktor juga semakin lama. Dengan demikian proses degradasi biologis aerob berlangsung semakin baik yang artinya semakin kecil pula kadar BOD yang diperoleh. Dengan demikian, waktu pengolahan (waktu degradasi) sangat berpengaruh terhadap penurunan kadar BOD pada limbah cair Hotel Aston. Nilai penurunan kadar BOD berbanding lurus terhadap masa inkubasi (waktu degradasi), semakin lama masa pengolahan (waktu degradasi), 
maka semakin tinggi nilai efisiensinya. Nilai efisiensi menunjukkan seberapa besar penurunan kadar yang terjadi pada limbah terhadap kadar pencemar tertentu. Semakin besar nilai persentase yang diperoleh, maka semakin tinggi nilai efisiensinya. Pada hasil penelitian sudah memenuhi baku mutu lingkungan.

\section{Parameter TSS}

Penurunan konsentrasi TSS semakin lama semakin meningkat. Menurut Madarina (2016), kandungan TSS tersaring melalui celah-celah media dan biofilm yang membungkus permukaan media untuk reaktor terlekat. Hal ini membuktikan bahwa proses biofilter dapat menghilangkan padatan tersuspensi dengan baik. Pengolahan limbah cair Hotel Aston dengan unit pengolahan reaktor terlekat mampu menurunkan konsentrasi TSS hingga dibawah baku mutu PerMen LH nomor 68 tahun 2016. Hasil pengukuran TSS dapat dilihat pada Tabel 5

Tabel 5. Penurunan Parameter TSS

\begin{tabular}{ccccc}
\hline PERLAKUAN & $\begin{array}{c}\text { KONSENTRASI } \\
\text { AWAL }(\mathbf{m g} / \mathbf{l})\end{array}$ & $\begin{array}{c}\text { SETELAH } \\
\text { DIOLAH }(\mathbf{m g} / \mathbf{l})\end{array}$ & $\begin{array}{c}\text { EFEKTIVITAS } \\
\text { PENURUNAN } \\
(\boldsymbol{\%})\end{array}$ & $\begin{array}{c}* \text { BAKU MUTU } \\
(\mathbf{m g} / \mathbf{l})\end{array}$ \\
\hline TERLEKAT & 78 & 8 & 89,74 & 30 \\
KONTROL & 50 & 35,89 & \\
\hline PermenLHK/68/2016 & &
\end{tabular}

Berdasarkan Tabel 5 konsentrasi awal parameter TSS sebesar $78 \mathrm{mg} / \mathrm{L}$ didapat hasil pengolahan reaktor terlekat untuk parameter TSS dengan waktu pengolahan selama 7 hari didapat penurunan $8 \mathrm{mg} / \mathrm{L}$. Hasil pengamatan TSS limbah cair Hotel Aston pada reaktor terlekat dapat dilihat pada Gambar 7

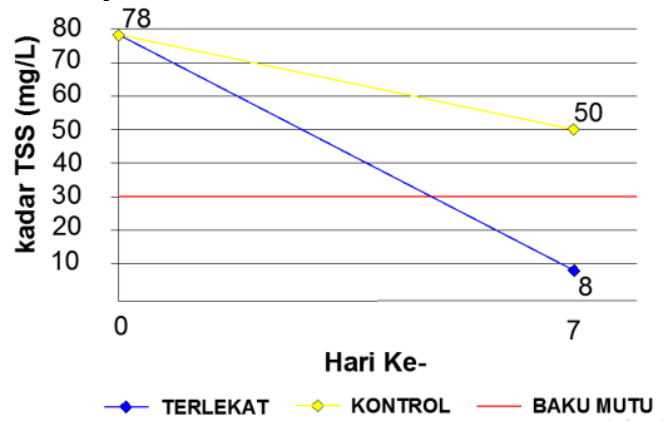

Gambar 7 Grafik rata-rata pengukuran TSS pada proses pengolahan

Penurunan TSS pada reaktor terlekat dikarenakan mikroorganisme yang berkoloni melekat pada media Kaldnes K3 lebih cepat untuk menguraikan zat organik yang tersuspensi. Perputaran media lekat Kaldnes K3 memberikan oksigen yang cukup bagi mikroorganisme yang terdapat pada media lekat untuk proses oksidasi aerob dan mengubah bahan organik menjadi lebih sederhana dan mensintesis sel-sel baru. Pengolahan limbah cair dengan lapisan biofilm sebagian besar proses penguraian terjadi pada permukaan media lekat (MetCalf and Eddy,2003). Dalam penelitian ini, semakin lama waktu kontak media dengan limbah cair dan udara semakin besar penurunan konsentrasi BOD. Grafik penurunan parameter BOD selama pengolahan dengan reaktor tersuspensi dan reaktor terlekat dapat dilihat pada Gambar 8. 


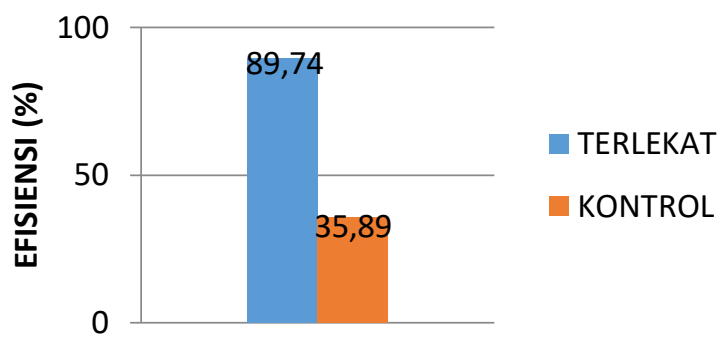

Gambar 8. Grafik efisiensi penurunan TSS

Hasil penurunan konsentrasi TSS. Efisiensi reaktor terlekat sebesar 89,74\% selama 7 hari. dikarenakan pada reaktor terlekat tersebut terdapat mikroorganisme yang berkoloni melekat pada media Kaldnes K3 dan mikroorganisme tersuspensi sehingga lebih cepat untuk menguraikan zat organik. Menurut kholif (2018), pengolahan dengan media lekat kaldnes sebanyak 30\% didapat penurunan lebih tinggi pada pengolahan limbah domestik sebesar 90\% pada hari ke-7, hal ini dikarenakan adanya proses pengendapan dan resirkulasi sehingga dapat membantu menurunkan konsentrasi TSS dan juga dipengaruhi oleh waktu tinggal air limbah dikarenakan semakin lama air limbah tinggal di dalam reaktor semakin banyak padatan tersuspensi yang terserap oleh lapisan biofilm sehingga efisiensi penurunan TSS semakin tinggi.

\section{PENUTUP}

\section{Kesimpulan}

Berdasarkan hasil dan pembahasan yang diperoleh penelitian ini dapat diambil kesimpulan yaitu limbah cair Hotel Aston memiliki karakteristik kandungan BOD sebesar 109,81 mg/l, dan kandungan TSS sebesar $78 \mathrm{mg} / \mathrm{l}$ dari nilai tersebut mengacu pada baku mutu PerMen LH nomor 68 tahun 2016 tentang baku mutu air limbah domestik masih di atas baku mutu lingkungan dan perlu adanya pengolahan sebelum dibuang ke lingkungan. Karakteristik konsentrasi BOD pada hari ke-7 dalam pengolahan biologis terlekat MBBR dengan media Kaldnes K3 rata-rata sebesar 7,28 mg/L, sedangkan konsentrasi TSS pada hari ke-7 pengolahan biologis terlekat MBBR dengan media Kaldnes K3 rata-rata sebesar $8 \mathrm{mg} / \mathrm{L}$. Efisiensi penurunan parameter pada pengolahan limbah cair Hotel Aston dengan waktu terbaik 7 hari dalam Pengolahan biologis terlekat MBBR dengan media Kaldnes K3 sebesar 93,37\% untuk parameter BOD dan 89,74\% untuk parameter TSS.

\section{Saran}

Untuk instalasi pengolahan limbah di Hotel Aston diperlukan perubahan unit pengolahan dari pengolahan biologi tersuspensi menjadi pengolahan biologi terlekat MBBR (Moving bed biofilm reactor) menggunakan media Kaldnes K3.

\section{UCAPAN TERIMA KASIH}

Puji dan syukur kami ucapkan kepada Tuhan Yang Maha Esa karena dengan rahmat dan Karunia-Nya kami dapat menyusun penelitian ilmiah tentang Efisiensi Pengolahan Limbah Cair Hotel Menggunakan Moving Bed Biofilm Reactor (MBBR). Ucapan terima kasih tak lupa kami sampaikan kepada ibu Laili Fitria S.T., M.T, dan ibu Ulli Kadaria S.T., M.T., selaku dosen pembimbing kami yang telah memberikan dan membimbing kami dalam menyelesaikan penelitian ini

\section{DAFTAR PUSTAKA}

Al Kholif Muhammad, Joko Sutrisno dan Ilham Dwi Prasetyo, 2018. Penurunan Beban Pencemar pada Limbah Domsetik Mengunakan Moving Bad Biofilm Reactor (MBBR), 
AL-ARD Jurnal Teknik Lingkungan Vol.4 No.1. Universitas PGRI Adi Buana (UNIPA) Surabaya.

Kusuma Dhimas Aji , Laili Fitria, Ulli Kadaria. 2019. Pengolahan Limbah Laundry dengan Metode Moving Bad Biofilm Reaktor (MBBR), Jurusan Teknik Lingkungan Fakultas Teknik Universitas Tanjungpura, Pontianak.

Mardiyana. 2008. Pengolahan yang Tepat bagi Limbah Cair. modul-pengolahan-air.

Metcalf dan Eddy. 2003. Wastewater Engineering: Treatment, Disposal and Reuse. McGraw-Hill, Inc.: New York.

Ozkan, Okray. 2011. Characterization And Assessment Of A Large-Scale Domestic Advanced Wastewater Treatment Plant In Turkey. Turkey, Environ Mount Assess.

Sayekti.; Rini.; Riyanto Haribowo.; Yohana Vivit dan Agung Prabowo. 2012. Studi Efektifitas Penurunan Kadar BOD, COD dan NH3 pada Limbah Cair Rumah Sakit Dengan Rotating Biological Contactor. Universitas Brawijaya. Malang.

SNI Nomor 69-8959-2008 Metode Pengambilan Contoh Air Limbah

Sihite, S. D. 2013. Laundry Dengan Teknologi Biofilm Yang Menggunakan Media Filter Serat Plastik Dan Tembikar Yang Tersusun Secara Random. Teknik Lingkungan UNDIP. Semarang.

SNI Nomor 69-8959-2008 Metode Pengambilan Contoh Air Limbah

Metcalf dan Eddy. 2003. Wastewater Engineering: Treatment, Disposal and Reuse. McGraw-Hill, Inc.: New York. 